\title{
Are All Our Pes Planus Diagnoses Correct?
}

\author{
Tüm Pes Planus Tanılarımız Doğru Mu?
}

\author{
(D) Mesut Uluöz, (1) Kemal Yüce, (1) Vahid Erdal Battal, (1) Osman Çiloğlu \\ University of Health Sciences Turkey, Adana City Training and Research Hospital, Clinic of Orthopaedic and Traumatology, Adana, Turkey
}

\section{$\ddot{0} z$}

Amaç: Pes planusun tanısı için birçok radyolojik kriter tanımlanmıştır. Bu çalışmada radyolojik kriterlerin birbiriyle ilişkisini araştırmayı amaçladık.

Gereç ve Yöntem: Araştırmada, askeri personel alım başvurusunda kullanılmak adına sağlık raporu almak için hastanemize gelen adaylardan planus tanısından dolayı elenen 126 aday geriye dönük değerlendirildi. Ayakta basarak çekilmiş yan grafiler ve muayene bulguları değerlendirildi. Kalkaneal zemin açısı (KZA), talo-kalkaneal açı (TKA), talus-1.metatars açısı (TMA), talo-horizantal açı (THA) ölçüldü. KZA kendi içinde 0-10, 10-15, 15-20 olarak 3 gruba ayrıldı ve bu gruplar diğer üç açıyla kıyaslandı.

Bulgular: Muayene bulgusu değerlendirildiğinde 1. Grupta sağ ve sol ayakların tamamının planus olduğu görülürken; 2. Grupta sağ \%21,7, sol \%7,7 3. Grupta sağ \%77,9 sol \%87,6 oranında ayakların sağlam olduğu görülmüştür. TKA her üç grupta da normal çıkmıştır. TZA ve TMA değerlerinde ise Grup 1'den Grup 3'e gidildikçe ayakların sağlam çıkma oranı artmaktadır. Talusu ve 1. metatarsı baz alan açılar, klinik muayene bulgularıyla korelasyon göstermektedir. KZA'ya göre elenen 126 aday eğer diğer açılara göre değerlendirilseydi; TZA'dan 51 kişi, TMA'dan 48 kişi, TKA'dan 5 kişi elenmiş olacaktı.

Sonuç: Klinik muayene bulgular ile en uyumlu açı meary açısıydı. Özellikle askeri personel alımında CP açısının ana kriter olarak alınması normal ayaklı adayları eleyecektir. Pes planus tanısında meary açısına öncelik verilmeli ve klinik muayene ile desteklenmelidir.

Anahtar Kelimeler: Düztabanlık, Meary Açısı, Kalkaneal Zemin Açısı

\section{Abstract}

Objectives: Many radiological criteria have been defined for the diagnosis of pes planus. In this study, we aimed to investigate the relationship between radiological criteria.

Materials and Methods: One hundred and twenty-six candidates who came to us to get a health report to be used in military personnel recruitment applications, who were eliminated due to planus diagnosis, were evaluated retrospectively. Lateral radiographs taken by standing up and examination findings were evaluated. Calcaneal picth angle (CP), talo-calcaneal angle (TC), talus-1. metatarsal angle (TM) (meary), talo-horizontal angle (TH) were measured. CP was divided into 3 groups as $0-10,10-15,15-20$, and these groups were compared with the other three angles.

Results: When the examination were evaluated, While it was observed that all feet were planus in Group 1 ; in the $2^{\text {nd }}$ Group, the right feet were $21.7 \%$, the left 7.7\%, in the $3^{\text {rd }}$ Group the right $77.9 \%$ and the left $87.6 \%$ feet were healthy. TKA was normal in all three groups. On the other hand, in TZA and TMA values, as you go from Group 1 to Group 3, the rate of foot recovery increases. Angles based on the talus and $1^{\text {st }}$ metatarsal correlate with clinical examination findings. If 126 candidates were evaluated according to other angles; 51 people from TZA, 48 people from TMA, and 5 people from TKA would have been eliminated.

Conclusion: The angle most compatible with clinical examination findings was the meary angle. Especially in the recruitment of military personnel, considering the $\mathrm{CP}$ angle as the main criterion will eliminate candidates with normal feet. When diagnosing pes planus, the angle of meary should be prioritized and it should be supported by clinical examination.

Key Words: Pes Planus, Meary Angle, Calcaneal Pitch Angle

Yazışma Adresi/Address for Correspondence: Mesut Uluöz,

University of Health Sciences Turkey, Adana City Training and Research Hospital, Clinic of Orthopaedic and Traumatology, Adana, Turkey

Tel.: +90 3224559000 E-posta: mesutuluoz@hotmail.com ORCID ID: orcid.org/0000-0003-0319-3832

Geliş Tarihi/Received: 05.04.2021 Kabul Tarihi/Accepted: 11.06.2021

๑Telif Hakkı 2021 Ankara Üniversitesi Tıp Fakültesi

Ankara Üniversitesi Tıp Fakültesi Mecmuası, Galenos Yayınevi tarafından yayınlanmıştır.

Yayınlanan tüm içerik CC BY-NC-ND lisansı altındadır. 


\section{Introduction}

Although pes planus is a common disease, it has no clear definition. Some authors describe the eversion and pronation of the heel accompanying the forefoot supination; there were those who defined this pathology as persistent and effective pronation of the foot during weight bearing $(1,2)$. This disease, which causes walking and posture disorders at all ages, is a common and important disease $(3,4)$. Diagnosis in pes planus is made by clinical and radiological evaluation. However, there is no consensus on their values (5). While pain is not encountered in childhood, adult pain comes to the fore. Foot, calf pain and weakness ocur with walking and standing (6). For this reason, pes planus is an obstacle to some profession groups that have to stand on foot for long periods.

In the recruitment of military personnel, if the calcaneal ground angle is below 20 degrees, a flatfoot diagnosis is made and eliminated regardless of other angles or the person's clinical findings (Turkish Armed Forces, Gendarme General Command and the Coast Guard Command Health Skills Regulation Clause 66 A, Table Annex D) (7). We aimed to compare this angle, which causes important results, with other angles used in pes planus.

\section{Materials and Methods}

For this study had ethical approval from University of Health Sciences Turkey, Adana City Training and Research Hospital Clinical Research Ethics Committee (no: 524/2019). Our study was carried out in accordance with the Helsinki Declaration Principles. One hundred twenty-six male candidates aged 1825 who applied to the health board of our hospital for military personnel qualifications and were eliminated due to flatfoot were screened retrospectively. They applied in March and April 2019. The standing side foot radiographs of both feet were evaluated. (The X-rays were examined over the Akgün radiological system installed in our hospital). Those who previously had an operation on their feet were excluded from the study: Calcaneal pitch (CP) angle, talo-calcaneal angle (TC), talus-1. Metatarsal angle (TM) (meary) (8), talo-horizontal angle (TH) (9) were measured by three different orthopedists and averaged.

The CP angles were divided into three groups, with the first group being 0-10 degrees, the second group 10-15 degrees, and the third group 15-20 degrees. Other angle parameters within normal limits were considered to be negative and those outside the normal range to be positive. $\mathrm{CP}$ angle groups were statistically compared with other angle parameters.

Clinical examinations of the patients were evaluated. In the clinical examination, it was checked whether the feet were flexbl or rigid and whether there was a planus appearance at the inspection. The distributions in the three groups of the CP angle were evaluated.

\section{Statistical Analysis}

SPSS 23.0 package program was used for statistical analysis of the data. Categorical measurements were summarized as numbers and percentages, while continuous measurements were summed as mean, deviation and minimum-maximum. Pearson's chi-squared test was used to compare categorical variables. In comparing the continuous measurements between the groups, the distributions were checked and independent student t-test analysis was applied to the binary variables. Statistical significance level was taken as 0.05 in all tests.

\section{Results}

The comparison of the right foot calcaneal tilt angle with TH, TM and TC angles is shown in Table 1.

Correlation of the right $\mathrm{CP}$ angle with $\mathrm{TH}(\mathrm{p}=0.845)$, TM $(p=0.092)$, TC $(p=0.837)$ angles was compared. There were no statistically significant differences $(p>0.05)$. The comparison of the left foot calcaneal tilt angle with TH, TM and TC angles is shown in Table 2.

Table 1: Comparison of right foot calcaneal pitch angle and $\mathrm{TH}$, TM and TC angles

\begin{tabular}{|c|c|c|c|c|c|}
\hline \multirow{2}{*}{ Right foot } & & \multicolumn{3}{|c|}{ Right calcaneal pitch angle } & \multirow[b]{2}{*}{ p-value } \\
\hline & & $\begin{array}{l}0-10 \\
(n=8)\end{array}$ & $\begin{array}{l}10-15 \\
(n=46)\end{array}$ & $\begin{array}{l}15-20 \\
(n=72)\end{array}$ & \\
\hline \multirow{2}{*}{ TH angle } & $<25$ & $4(50.0)$ & $28(60.9)$ & $43(59.7)$ & \multirow{2}{*}{0.845} \\
\hline & $>25$ & $4(50.0)$ & $18(39.1)$ & $29(40.3)$ & \\
\hline \multirow{2}{*}{ TM angle } & $<4$ & $2(25.0)$ & $30(65.2)$ & $45(62.5)$ & \multirow{2}{*}{0.092} \\
\hline & $>4$ & $6(75.0)$ & $16(34.8)$ & $27(37.5)$ & \\
\hline \multirow{2}{*}{ TC angle } & $\begin{array}{l}25-50 \\
\text { normal }\end{array}$ & $8(100.0)$ & $44(95.7)$ & 69 (95.8) & \multirow{2}{*}{0.837} \\
\hline & $\begin{array}{l}>50 \\
\text { above }\end{array}$ & $0(0.0)$ & $2(4.3)$ & $3(4.2)$ & \\
\hline
\end{tabular}

TH: Talo-horizontal angle, TM: Talus 1. metatarsal angle, TC: Talocalcaneal angle

Table 2: Comparison of left foot calcaneal pitch angle and $\mathrm{TH}$, TM and TC angles

\begin{tabular}{|c|c|c|c|c|c|}
\hline \multirow{3}{*}{ Left foot } & & \multicolumn{4}{|c|}{ Left calcaneal pitch angle } \\
\hline & & $0-10$ & $\begin{array}{l}10-15 \\
(n-38)\end{array}$ & $\begin{array}{l}15-20 \\
(0-81)\end{array}$ & p-value \\
\hline & & n (\%) & n (\%) & n (\%) & \\
\hline \multirow{2}{*}{ TH angle } & $<25$ & $2(28.6)$ & $23(60.5)$ & $58(71.6)$ & \multirow{2}{*}{$0.050^{*}$} \\
\hline & $>25$ & $5(71.4)$ & $15(39.5)$ & $23(28.4)$ & \\
\hline \multirow{2}{*}{ TM angle } & $<4$ & $2(28.6)$ & $26(68.4)$ & $64(79.0)$ & \multirow{2}{*}{$0.012^{*}$} \\
\hline & $>4$ & $5(71.4)$ & $12(31.6)$ & $17(21.0)$ & \\
\hline \multirow{2}{*}{ TC angle } & $\begin{array}{l}25-50 \\
\text { normal }\end{array}$ & $7(100.0)$ & $36(94.7)$ & $80(98.8)$ & \multirow{2}{*}{0.370} \\
\hline & $>50$ & $0(0.0)$ & $2(5.3)$ & $1(1.2)$ & \\
\hline
\end{tabular}

TH: Talo-horizontal angle, TM: Talus 1. metatarsal angle, TC: Talocalcaneal angle 
It was found that there was no statistically significant difference between left foot $\mathrm{CP}$ angle and TC angles ( $p=0.370)$ ( $p>0.05$ ). Patients had higher TH angles in the $<25$ group. In the left foot CP angle, the ratio of those in the 15-20 group was found to be statistically significantly higher than that of the other group $(p<0.05)$. The proportion of patients in the 15-20 group with a TMA angle below 4 was found to be statistically significantly higher than those above $4(p=0.012, p<0.012)$.

In the foot examination for 252 feet of 126 candidates; no foots had rigit planus appearance; in group 1, all the right and left feet had planus appearance. While in the second and third groups planus appearance ratio decreased gradually (Table 3).

In our study the right foot $\mathrm{TH}$ angle was evaluated as normal in $50 \%$ of group 1, 60\% in group 2, and $60 \%$ in group 3 . The TM angle was found to be normal in 25\% of group 1, 65\% of group $2,62 \%$ of group 3 . The TC angle was found $100 \%$ normal in group 1,95\% in group 2, and 95\% in group 3.

For the left foot TH angle was found to be normal in $28 \%$ of group $1,60 \%$ of group 2 and $58 \%$ of group 3 . When the TM angle is evaluated, $28 \%$ in group 1,68\% in group 2 and $79 \%$ in group 3 were found to be intact. The left TC angle was found normal in 100\% of group 1,94\% of group 2, and 98\% of group 3. Table 3 shows the ratio of feet with planus appearance to the number of feet within the group in the examination. In-group proportions and percentages of feet accepted as normal feet in the examination are shown in Table 4.

\section{Discussion}

Pes planus is a pathology that we frequently encounter in the clinic. Many radiological criteria have been defined for the diagnosis of this disease. However, there is no consensus among authors about the normal limits of these criteria (5). Therefore, the patient's clinical findings are more important in the diagnosis and treatment decision. To interpret these results, group 1, which was diagnosed as pes planus by physical examination, was $100 \%$ healthy according to the TC angle. All these conclusions have led us to question the reliability of this angle.

$\begin{aligned} & \text { Table 3: The ratio of feet with planus appearance in the } \\ & \text { examination to the number of feet within the group }\end{aligned}$
$\begin{array}{llll}\text { Group } 1 & \text { Group } 2 & \text { Group 3 } \\ \text { Left } & 7 / 7 & 33 / 38 & 10 / 81 \\ \text { Right } & 8 / 8 & 36 / 46 & 8 / 72\end{array}$

Table 4: Intra-group ratios and percentages of feet that are accepted as normal feet in the examination

\begin{tabular}{lllll|} 
& Group 1 & Group 2 & Group 3 & \\
Left & $0 / 7(0 \%)$ & $5 / 38(7.7 \%)$ & $71 / 81(87.6 \%)$ & $76 / 126(60 \%)$ \\
\hline Right & $0 / 8(0 \%)$ & $10 / 46(21.7 \%)$ & $64 / 72(77.9 \%)$ & $74 / 126(58 \%)$
\end{tabular}

It is noteworthy that the TM and TH angles rate of survival increase from group 1 to group 3, which is consistent with physical examination findings. Although this situation is observed evidently in the table, it is not found statistically significant. We attribute this statistical insignificance to the unbalanced distribution of the number of patients in the groups. If 126 candidates who were eliminated according to the $\mathrm{CP}$ angle were evaluated according to other angle parameters, only 51 people from $\mathrm{TH}, 48$ people from TM and 5 people from TC would be eliminated.

Candidates in our study were diagnosed for the first time during the qualification period and all of them had performed full time military service without any problems. We see that more than half of the candidates' foot examination in terms of planus is normal and this rate exceeds $80 \%$ in group 3 .

Another evaluation method used in the diagnosis of planus is the evaluation of static footprint. In a study by Gün et al. (10) in 2011, static footprints were taken with harris mat. These footprints were evaluated by three different methods; 1-Staheli index (11) 2-Chippaux-Smirak index (12), 3-Grivas Classification System (12).

These footprint evaluations were compared both among themselves and with radiological parameters ( $\mathrm{CP}, \mathrm{TH}, \mathrm{TM})$. Researchers detected pes planus in 34 cases according to talometatarsal angle, 14 according to talus-ground angle, and 12 cases according to calcaneusground angle, out of 52 cases of pes planus detected according to Sl. Compared to our study, Gün et al. (10) accepted a CP angle value of fewer than 15 degrees which is more selective. In our study, if we exclude 15 degrees and above, group 3 will be removed and the values between the two studies will become correlated. As a result, there was no significant correlation neither between the footprints nor the radiological aspects. Kanatli et al. (13) revealed a correlation between $\mathrm{TH}$ and $\mathrm{TM}$ and $\mathrm{SI}$ in childhood pes planus, and no correlation with calcaneus ground (CP) angle.

We agree with the authors who think that diagnosing a three-dimensional disease like pes planus with two-dimensional radiological values is not very accurate (14). The axis of the calcaneus is not parallel with the medial longitudinal arch. Therefore we believe that the patient's load transfer to lateral or medial, trying to balance on one feet during X-ray, might change the $\mathrm{CP}$ angle. We think $\mathrm{CP}$ angle is grossly affected by $\mathrm{X}$-ray shooting mistakes. This situation causes false positivity. $\mathrm{CP}$ and TC results were incompatible with other angles on the foot-side and examination findings. All these results suggest that the side radiography is not an appropriate method for the evaluation of the calcaneus. Whether the change of maximum load point on foot during $\mathrm{X}$-ray shooting might affect $\mathrm{CP}$ angle measurements will be evaluated in another study. 
In a study we are currently conducting on intact feet, while standing on one leg, neutral, lateral scopy images were taken by placing weight on the medial of the foot and weight on the lateral foot. When the CP angles were compared, there was no significant difference in the shooting with the neutral and lateral load, while the shooting with the medial load was significantly lower than the others. There was no significant difference in meary angles in all three groups.

We think that the meary angle (TM) is less affected by X-ray errors because both the talus and the first axis of the metatarsal are in the same direction and the axes of the mediallongitudinal arch and the tarsometatarsal angle are very close to each other. The fact that $\mathrm{TH}$ and $\mathrm{TM}$ correlated with the physical examination results in our study supports this argument.

\section{Study Limitation}

The weakness of our study is that the candidates were not diagnosed with a podogram.

\section{Conclusion}

As a result, our study showed that radiological measurements contradict each other which is consistent with the literature information. However, since TH and TM angles are more correlated with physical examination, we would like to emphasize that these angles should be mainly considered during diagnosis and should be supported by clinical examination. In addition, working on ensuring the standardization of the X-ray shooting process and even the development of the auxiliary tools to be used in the shooting will largely eliminate the problems in diagnosis. This will be especially important during the implementation of the criteria in military personnel recruitment regulation.

\section{Ethics}

Ethics Committee Approval: For this study had ethical approval from University of Health Sciences Turkey, Adana City Training and Research Hospital Clinical Research Ethics Committee (no: 524/2019).

Informed Consent: Retrospective study.

Peer-reviewed: Externally peer-reviewed.

\section{Authorship Contributions}

Surgical and Medical Practices: M.U., Concept: M.U., Design: M.U., Data Collection or Processing: M.U., K.Y., V.E.B., Analysis or Interpretation: M.U., Literature Search: M.U., Writing: M.U., O.Ç.

Conflict of Interest: No conflict of interest was declared by the authors.

Financial Disclosure: The authors declared that this study received no financial support.

\section{References}

1. Ferciot CF. The etiology of developmental flatfoot. Clin Orthop Relat Res. 1972;85:7-10.

2. Giannini S. Kenneth A. Johnson Memorial Lecture. Operative treatment of the flatfoot: why and how. Foot Ankle Int. 1998;19:52-58.

3. Benvenuti F, Ferrucci L, Guralnik JM, et al. Foot pain and disability in older persons: an epidemiologic survey. J Am Geriatr Soc. 1995;43:479-484.

4. Kohls-Gatzoulis J, Angel JC, Singh D, et al. Tibialis posterior dysfunction: a common and treatable cause of adult acquired flatfoot. BMJ. 2004;329:1328-1333.

5. Shih YF, Chen CY, Chen WY, et al. Lower extremity kinematics in children with and without flexible flatfoot: a comparative study. BMC Musculoskelet Disord. 2012;13:31.

6. Henceroth WD, Deyerle WM. The acquired unilateral flatfoot in the adult: some causative factors. Foot Ankle. 1982;2:304-308.

7. https://www.mevzuat.gov.tr/MevzuatMetin/21.5.20169431.pdf. 2020.

8. Sinha S, Song HR, Kim HJ, et al. Medial arch orthosis for paediatric flatfoot. J Orthop Surg (Hong Kong). 2013;21:37-43.

9. Shirai $Y$, Wakabayashi $K$, Wada I, et al. Flatfoot in the contralateral foot in patients with unilateral idiopathic clubfoot treated using the foot abduction brace. Medicine (Baltimore). 2017;96:e7937.

10. Gün K, Saridogan M, Uysal Ö. Correlation of Footprint and Radiographic Measurement Methods in the Diagnosis of Pes Planus. Turk J Phys Med Rehabil. 2012;58:283-287.

11. Staheli LT, Chew DE, Corbett M. The longitudinal arch. A survey of eight hundred and eighty-two feet in normal children and adults. J Bone Joint Surg Am. 1987;69:426-428.

12. Stavlas $P$, Grivas $T B$, Michas $C$, et al. The evolution of foot morphology in children between 6 and 17 years of age: a cross-sectional study based on footprints in a Mediterranean population. J Foot Ankle Surg. 2005;44:424428.

13. Kanatli $\mathrm{U}$, Yetkin $\mathrm{H}$, Cila E. Footprint and radiographic analysis of the feet. J Pediatr Orthop. 2001;21:225-228.

14. McPoil TG, Vicenzino B, Cornwall MW, et al. Can foot anthropometric measurements predict dynamic plantar surface contact area? J Foot Ankle Res. 2009;2:28. 